\title{
A essência da linguagem em Heidegger
}

\author{
Karl Heinz Efken ${ }^{1}$ \\ Márcio José da Silva ${ }^{2}$ \\ recebido: $12 / 2014$ \\ aprovado: $12 / 2014$
}

RESUMO:A finalidade deste artigo é mostrar como Heidegger concebe a essência da linguagem. Para isso, travamos uma conversa com ele mediante $A$ Caminho da Linguagem, um diálogo que privilegia mais a escuta que a fala. Ouvimos seu apelo acerca da relação entre poesia e pensamento e da essência da linguagem. Analisamos quais as implicações do seu interesse pela etimologia e o que há em comum entre ele e os semanticistas da enunciação. O filósofo nos diz que, se pararmos, estamos mais perto da linguagem do que nos movimentando em sua busca.

ABSTRACT:This article intends to show how Heidegger conceives the essence of language. To achieve so, we talk to him through On the Way to Language, a dialogue which gives more importance to listening than to speaking. We have heard his appeal concerning the relationship between poetry, thought and the essence of language. We have analysed what are the implications of his interest in etymology and what is in common between the semanticists of enunciation and Heidegger. This German philosopher says to us that, if we stop, we are closer the language than moving towards it.

\section{CONSIDERAÇÕES INICIAIS}

\footnotetext{
${ }^{1}$ Doutor em Filosofia pela Pontifícia Universidade Católica do Rio Grande do Sul; pesquisador na área de filosofia, educação, ética e direito; professor do Curso de Filosofia, do Mestrado e do Doutorado em Ciências da Linguagem da UNICAP (Universidade Católica de Pernambuco).

${ }^{2}$ Mestrando do Curso de Ciências da Linguagem da UNICAP e professor efetivo de português e de inglês do Instituto Federal de Pernambuco Campus Recife (marxl@ hotmail.com).
} 
Não queremos apenas ser compreendidos ao escrever, mas igualmente não ser compreendidos. De forma nenhuma constitui objeção a um livro o fato de uma pessoa achálo incompreensível: talvez isso estivesse justamente na intenção do autor — ele não queria ser compreendido por "uma pessoa". Todo espírito e gosto mais nobre, quando deseja comunicar-se, escolhe também os seus ouvintes; ao escolhê-los, traça de igual modo a sua barreira contra "os outros". Todas as mais sutis leis de um estilo têm aí sua procedência: elas afastam, criam distância, proíbem "a entrada", a compreensão, como disse enquanto abrem os ouvidos àqueles que nos são aparentados pelo ouvido.

Friedrich Nietzsche ${ }^{3}$

Interpretar o pensamento de Martin Heidegger não é tarefa simples. O filósofo funde pensamento e poesia. E como se sabe, a poesia costuma esconder o significado na metáfora, de tal modo que pode torná-lo um enigma. Outra situação que ocorre por meio da metáfora é justamente o contrário do enigma: a plurissignificação. Desse modo, por um lado, é sempre arriscado interpretar o discurso de Heidegger; por outro, ele está aberto a muitas interpretações, já que o pensamento na poesia é um universo de possibilidades. E engana-se quem se acha o dono do sentido do texto heideggeriano.

Neste artigo, nossa análise limita-se a $A$ Caminho $d a$ Linguagem. Só esse texto já nos oferece muita dificuldade, além da sensação de estarmos pisando em ovos ao tentar parafrasear o dizer de Heidegger. De qualquer modo, julgamos ser suficiente para nosso artigo que nos limitemos a esse livro, pois seria

${ }^{3}$ NIETZSCHE, F. A Gaia Ciência. Tradução, notas e posfácio de Paulo César Lima de Souza. São Paulo: Companhia das Letras, 2001. p. 284, grifo do autor. 
muita pretensão abarcar mais que isso num gênero textual com esta brevidade.

É válido ainda esclarecer que não analisamos $A$ Caminho $d a$ Linguagem escrutinando cada enunciado. Isso seria inviável por várias razões. Para realizarmos tal empresa, teríamos de lançar uma espécie de enciclopédia no que ela tem de vasta. Além disso, não nos pejamos de assumir que ainda não estamos prontos para escutar a todo o apelo da linguagem de Heidegger, o que só testifica o vigor de seus discursos. João Cabral de Melo Neto advertiu que a poesia lida uma vez, ela não é lida, mas mal lida. Sendo assim, só muita dedicação ao trabalho de Heidegger e uma experiência com o que a linguagem fala por meio dele possibilitar-nos-iam uma aproximação maior do sentido não só de A Caminho da Linguagem, mas de toda sua reflexão, uma vez que sua filosofia afigura-se-nos bem mais literária que a de Nietzsche, tantas vezes citado por Heidegger.

$\mathrm{O}$ que faremos, efetivamente, neste artigo é investigar em $A$ Caminho da Linguagem o que possa nos aproximar da essência da linguagem. Para isso, levaremos em conta não só que Heidegger afirma, mas também o que ele nos deixar inferir pelo modo como conduz sua escrita e por suas crenças inconscientes. Desde que já admitimos certa obscuridade no estilo de Heidegger, o que nos torna ainda mais heideggerianos, e que só nos interessa seus enunciados mais diretamente relacionados com a essência da linguagem, nosso procedimento supõe, é óbvio, uma seleção de sua mensagem. 


\section{A CONVERSA DO PENSAMENTO COM A POESIA EVOCA A ESSÊNCIA DA LINGUAGEM}

De onde surgiu a lógica na mente humana? Certamente do ilógico, cujo domínio deve ter sido enorme no princípio. Mas incontáveis outros seres, que inferiam de maneira diversa da que agora inferimos, desapareceram: e é possível que ela fosse mais verdadeira!

Friedrich Nietzsche $e^{4}$

Mencionamos, acima, que um dos entraves da interpretação do texto poético é sua característica paradoxal de ser tanto enigmático quanto polissêmico e que isso dificultava bastante a assimilação da filosofia de Heidegger. Quando se afirma que um texto é polissêmico, isso não requer esclarecimentos, mas, o que significa aqui seu caráter enigmático? A poesia também pode fazer-nos esbarrar na interpretação. Ela, muitas vezes, não nos deixa seguir, não nos permite avançar. Isso acontece, porque ainda não estamos prontos para o sentido de determinados enunciados, não conseguimos escutar sua mensagem, ou mesmo pela obscuridade do texto. A poesia surrealista, por exemplo, assim como as demais artes nesse estilo, requer uma escuta demorada. Lembremos que mal lido é o poema que é lido somente uma vez. Isso é ainda mais verdadeiro para a poesia surrealista. A polissemia, curiosamente, pode funcionar como um enigma. Entre tantas vias disponíveis, qual escolher? Quanto

\footnotetext{
${ }^{4}$ NIETZSCHE, op. cit., p. 139.

ÁGORA FILOSÓFICA

.v. 1. n. 2 (2014), pp.235-258 e-ISSN 1982-999x
} 
à plurissignificação da poesia, Heidegger (2003, p. 63) confirma o que vimos sustentando, e faz uma ressalva:

A linguagem da poesia é essencialmente polissêmica e isso de um jeito muito próprio. Não conseguiremos escutar nada sobre a saga do dizer poético enquanto formos ao seu encontro guiados pela busca surda de um sentido unívoco [...] Essa polissemia da saga do dizer poético não se dispersa todavia numa confusão indeterminada de sentidos.

Observa-se que há um limite para essa polissemia. O próprio texto em si traçará até aonde se pode ir. Nesse trecho, Heidegger parece dar-nos mais uma vez uma indicação da essência da linguagem e sua relação com o texto poético: a polissemia. $\mathrm{O}$ pensamento lógico, sem poesia, é um entrave à essência da linguagem no que ele tem de unívoco, na sua pretensão à univocidade.

O texto poético é onde a essência da linguagem mais pode transparecer. O sentido do texto poético aparece a partir do momento em que o poeta sai de cena. É quando a linguagem fala. Nesse momento, a univocidade vai embora e dá lugar à polissemia. E por que não ao equívoco?

Percebamos como é fácil perder-se a caminho da linguagem. $\mathrm{Ou}$ achar-se? Uma das operações mais comuns de quem almeja fazer-se compreender é a formulação de uma paráfrase. Contudo, Heidegger reconhece que a tradução de um enunciado é dizer uma coisa nova, quando se trata de um enunciado poético, ele chama de "audácia", porquanto nenhum texto é mais arisco à paráfrase que o texto poético quer na mesma língua, quer numa língua estrangeira. Como então explicar, se, ao 
tentarmos fazer isso, dizemos uma coisa nova, diferente? Parece mesmo que estamos a caminho do equívoco.

Não podemos nos iludir ao supor que o pensamento tem uma natureza totalmente distinta, distante da poesia. Entre eles há uma vizinhança. O pensamento não seria o lugar da lógica e da exatidão, e a poesia o lugar da subjetividade. Heidegger ratifica sua posição e acrescenta o apelo de Nietzsche sobre essa questão:

O pensamento não é nenhum meio para o conhecimento. $\mathrm{O}$ pensamento abre sulcos no agro do ser. Por volta do ano de 1875, Nietzsche escreve o seguinte: "Nosso pensamento deve ter o cheiro forte de um trigal numa noite de verão". Quantos ainda possuem olfato para esse cheiro? (HEIDEGGER, 2003, p. 133).

A propósito, este outro sábio germânico assemelha-se a Heidegger no que ambos têm de antirracionalistas. Tanto um quanto o outro não viam no cientificismo o caminho do homem. A essência do homem está bem mais no passado que no presente. Heidegger presume o mesmo da essência da linguagem. Na citação, há uma preferência pela poesia em detrimento do pensamento. Isso ocorre, porque, nesse contexto, 'pensamento' significa 'ratio'. No entanto, reiteramos que Heidegger não compreende o pensamento como faria um racionalista ou um positivista; para ele, o pensamento verdadeiro é ilógico na acepção da palavra. Contudo, ele adverte que "há séculos nos alimentamos do preconceito de que o pensamento é coisa da ratio, ou seja, do cálculo em sentido amplo, falar sobre a vizinhança de pensamento e poesia parece sempre muito suspeito" (HEIDEGGER, 2003, p. 133). 


\title{
3. A ETIMOLOGIA COMO CHAVE PARA O SENTIDO
}

\begin{abstract}
O certo é que não poderíamos nos colocar nas condições da Renascença nem sequer nos imaginar nelas: nossos nervos não suportariam tal realidade, para não falar de nossos músculos. Essa incapacidade, porém, não é uma prova de progresso, mas apenas de uma constituição diferente, mais tardia, mais fraca, mais delicada, mais vulnerável, da qual resulta necessariamente uma moral rica em considerações.
\end{abstract}

Friedrich Nietzsche ${ }^{5}$

Nietzsche estava pensando no desenvolvimento da moral e do homem, especialmente do homem europeu, ao fazer essa reflexão. Porém, reputamos aceitável transferi-la para a mudança das palavras e do seu sentido. Há muita nostalgia na filosofia de Nietzsche. E o mesmo ocorre com Heidegger. Ambos olham para o passado como uma época melhor que a atual. "Ouçamos” esta asserção de Heidegger (2003, p. 28): “A conversa do pensamento com a poesia busca evocar a essência da linguagem para que os mortais aprendam novamente a morar

\footnotetext{
${ }^{5}$ NIETZSCHE, F. Crepúsculo dos ídolos ou como se filosofa com o martelo. Tradução, apresentação e notas de Renato Zwick. Porto Alegre, RS: L\&PM, 2009. p. 107. 
na linguagem." Isso significa que nosso caminho para a linguagem é um caminho de volta, para uma época em que o instinto imperava? Parece-nos que sim. Ao utilizar, com frequência, a etimologia em sua obra, Heidegger indica-nos que o sentido verdadeiro ${ }^{6}$ está no passado. O que é válido igualmente para a essência da linguagem.

$\mathrm{Na}$ linguística moderna, como consequência do êxito de Saussure em transformar a linguística em ciência, a etimologia, antes muito solicitada, perdeu seu prestígio. O linguista suíço deu preferência ao recorte sincrônico ${ }^{7}$, e a etimologia está mais associada com a diacronia. O recorte da realidade é a base do conhecimento científico. Saussure, aliás, apreciava bastante a diacronia; todavia, ela é incompatível com a ciência, ou melhor, com o método científico. No entanto, Heidegger, muito coerentemente, alinhado com o pensamento anticientífico, vai buscar na etimologia o sentido a que, efetivamente, devemos dar atenção, o sentido original:

Mas o que diz "estranho"? Estranho significa comumente o que não é familiar, o que não

\footnotetext{
${ }^{6}$ A etimologia estuda a origem e a evolução das palavras. A palavra é

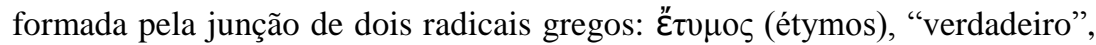
e de $\lambda$ ó ${ }^{\circ} \varsigma$ (lógos), "tratado", "estudo". Portanto, "etimologicamente", etimologia significa 'o estudo da verdade'. Percebamos, todavia, que se pode inferir um discurso de que a verdade está no passado, na origem. Platão, por exemplo, defendia que tudo que existe neste mundo é reflexo de uma matriz original que está no mundo das ideias. A etimologia é a busca do sentido original e da forma original de uma palavra.

7 'Diacronia' e 'sincronia' têm relação com a maneira como se estuda uma língua. A diacronia leva em conta várias fases do desenvolvimento de uma língua. Por exemplo, não apenas o português do século XXI, mas também o dos séculos anteriores, retrocedendo, numa sequência, até o Século XV para se chegar a alguma conclusão. A sincronia faz um recorte da língua, em qualquer época, e examina-a. De certo modo, o sentido etimológico de uma palavra, em última instância, é a acepção dela num ponto do tempo, algo sincrônico, mas, para se evocar esse significado, em alguns casos, tem sido utilizada a abordagem diacrônica.
}

ÁGORA FILOSÓFICA

.v. 1.n. 2 (2014), pp.235-258 e-ISSN 1982-999x 
nos diz respeito, mas sobretudo o que nos pesa e inquieta. No alto alemão, fremd vem de fram e tem propriamente o significado de: adiantarse rumo a um outro lugar, estar a caminho de..., o que se movimenta em direção ao que foi resguardado, reservado. O estranho está em travessia. Sua errância não é porém de qualquer jeito, sem determinação, para lá e para cá. $\mathrm{O}$ estranho caminho em busca do lugar em que pode permanecer em travessia. "O estranho" segue, sem quase dar-se conta, um apelo, o apelo de se encaminhar e pôr-se a caminho do que lhe é próprio (HEIDEGGER, 2003, p. 30-31).

Essa palavra é retirada de um poema de Georg Trakl intitulado Primavera da Alma. Posto que o sentido comum não seja negado abertamente nesse fragmento, o que se pode verificar é a primazia do sentido etimológico. É precisamente ele que Heidegger adota na sua leitura do poema. Entretanto, recorrer à etimologia implica um discurso, ainda que inconscientemente: a crença num sentido original, a concepção de uma decadência da verdade com o passar do tempo, diríamos, também, da essência. Essa não foi a única vez que Heidegger se serviu desse expediente, a prática é recorrente em sua pena em A Caminho da Linguagem. Ao tratar de dois outros poemas de Trakl, o filósofo traz mais um exemplo:

Delírio não é inventar sentido na insensatez. Wahn, delírio, origina-se do alto alemão wana e significa: sem. $\mathrm{O}$ delirante pensa e pensa mais do que qualquer um. Mas nisso ele fica sem o sentido dos outros. Ele é um outro sentido. "Sinnan" sentir, sentir-pensar, significa originariamente: viajar, almejar... pôr-se numa direção. A raiz indogermânica sent e set significa caminho. O desprendido é delirante porque está a caminho de outro lugar (HEIDEGGER, 2003, p. 43, grifo nosso). 
Há outras ocasiões em que Heidegger aplica seus saberes etimológicos. Por ora, esses dois excertos bastam. 'Estranho' e 'delírio’ tiveram sua essência semântica deturpada pelo tempo. A intervenção do filósofo restaura-lhes o sentido verdadeiro. Para Nietzsche, os séculos, outrossim, corromperam o vigor do homem. Heidegger, ao utilizar a etimologia, acredita que a essência da linguagem está na língua falada por esse homem do passado, ou melhor, na linguagem que falava esse homem da época virtuosa, no sentido nietzschiano.

Há, porém, uma contradição nesse posicionamento de Heidegger, pois ele valoriza a poesia, entre outros aspectos, devido a sua tendência à polissemia, o que representa uma negação da ideia de exatidão. No entanto, a etimologia ${ }^{8}$ não supõe a plurissignificação, mas um sentido único, original. Problema semelhante aparece quando Heidegger interpreta os poemas. Ele acaba selecionando um sentido. Por quê?

A análise do discurso enfrenta esse mesmo tipo de incongruência. A teoria defende que as sequências textuais são polissêmicas, mas ainda assim seus defensores interpretam textos. Qual o valor de uma interpretação, sabendo-se que é apenas uma entre tantas possíveis? Interpretar um texto já supõe univocidade. Do contrário, os analistas do discurso, e mesmo Heidegger, deveriam fazer uma interpretação que se conformasse com sua tese, isto é, apresentar vários sentidos para um texto, notadamente se se tratar de análise de poesia.

\footnotetext{
${ }^{8}$ Como ramo dos estudos linguísticos, a etimologia sopesa os diversos sentidos de uma palavra no tempo, no transcorrer dos séculos, mas, filosoficamente, discursivamente, a etimologia busca a verdade do sentido original.
} 


\title{
4. A ESSÊNCIA DA LINGUAGEM
}

\begin{abstract}
Mas onde a linguagem como linguagem vem à palavra? Raramente, lá onde não encontramos a palavra certa para dizer o que nos concerne, o que nos provoca, oprime ou entusiasma. Nesse momento, ficamos sem dizer o que queríamos dizer e assim, sem nos darmos bem conta, a própria linguagem nos toca, muito de longe, por instantes e fugidiamente, com o seu vigor.
\end{abstract}

Martin Heidegger ${ }^{9}$

Heidegger indica que não é possível chegar a uma resposta exata do que seja a essência da linguagem, pois, para ele, essa busca pela exatidão é um erro. Se utilizarmos o caminho traçado por Heidegger, vamos deixar de lado qualquer forma de exatidão. Não seria ela um desejo do homem de apreender a realidade com o intento de poder compreendê-la e dominá-la? Entretanto, a realidade não é um recorte morto. Ela é uma totalidade da qual fazem parte o lógico e o ilógico. O real é vivo e está em constante transformação. Rigorosamente falando, uma compreensão precisa da essência da linguagem vai de encontro ao que é a essência da linguagem. Por essa linha de pensamento, pode-se perceber que esse filósofo alemão não se alinha com a ciência, ou mesmo com uma filosofia mais racional e objetiva.

\footnotetext{
${ }^{9}$ HEIDEGGER, M. A caminho da linguagem. Tradução de Marcia Sá Cavalcante Schuback. Petrópolis, RJ: Vozes; Bragança Paulista, SP: Editora Universitária São Francisco, 2003. p. 123.

ÁGORA FILOSÓFICA .v. 1. n. 2 (2014), pp.235-258 e-ISSN 1982-999x
} 
Heidegger não por acaso utiliza a palavra 'caminho' no título de seu livro A Caminho da Linguagem. A escolha desse termo é deveras importante, porquanto supõe a ideia do devir. Quando estamos executando alguma atividade, é comum observarmos nas pessoas uma busca pelo fim desse trabalho. Porém, o mais importante é o processo em si, não seu fim, conquanto para que tenhamos uma completude, seja do que for, não podemos dispensar o fim, caso ele faça parte da coisa. Desse modo, deveríamos aproveitar mais o processo, o caminhar mesmo do que a chegada ao destino. Quase todos estão fixados no final, no destino e esquecem-se do prazer do caminho, de sua relevância maior. Para a lógica, a conclusão é o que vale. Heidegger, contudo, está longe de ser um lógico. Precisamos considerar mais as premissas do que a conclusão, mais as perguntas do que as respostas, a fim de acharmos uma sintonia com o pensamento heideggeriano.

Quando trata do ser, Heidegger aponta para um problema, um círculo vicioso, pois quem indaga não pode fazer isso de fora, está envolvido na resposta e na pergunta. Por que existe o questionamento do que é o ser? O homem, que é um ente, não pode jamais reclamar alguma objetividade nessa análise; aliás, como se pode notar, o conceito de objetividade a partir do homem é uma completa ilusão. O modo como filosofa Heidegger está de acordo com a realidade humana, não é algo inventado, como o conhecimento científico, mas se origina com base na experiência do que se vivencia. É como se ele afastasse tudo que adorna o pensamento, toda a tradição para ficar com que há de mais simples. Com efeito, Heidegger nem apreciaria 
ser chamado de filósofo, porque isso limita seu campo de ação. Isso excluiria, por exemplo, o que nele há de poeta.

Heidegger não aceita bem a ideia de círculo vicioso, mas uma espécie de "repercussão" quanto à questão do ser. Pode-se dizer o mesmo da linguagem, pois só podemos falar da linguagem a partir dela própria. E não é verdadeiro que a linguagem influencia nossa visão do que ela é, de sua essência? Seria possível libertar a linguagem de toda a tradição a fim de que ela ficasse pura e nos mostrasse sua essência? Ou seria viável elaborar uma linguagem que não tivesse os laços da linguagem natural para entendermos a essência da linguagem? Entretanto, quem criasse essa linguagem artificial não poderia fazer isso $e x$ nihilo, de maneira que o impasse persistiria, inclusive com o influxo da linguagem natural do inventor sobre a linguagem artificial fabricada, a qual, na prática revela-se uma ilusão da mesma noção de objetividade.

Além do problema em si de quem utiliza a linguagem, o homem é produto ele mesmo da linguagem também. Não é só o homem que fala a linguagem, mas ela também fala o homem, ou melhor, a linguagem vai além, fala o próprio ser: “A linguagem é a casa do ser." Será que poderíamos traduzir essa afirmação com esta: a linguagem é o fundamento do ser? A linguagem como alicerce de todas as coisas? Enquanto discute a essência da linguagem, Heidegger (2003, p.124-125) apresenta-nos mais um poema de Georg Trakl: A Palavra, em que há este verso: “Assim aqui nada repousa sobre razão profunda". Um indicativo da deusa Norna ${ }^{10}$ de que a essência buscada por Platão e Sócrates não

10 "Norna é deusa do destino na mitologia nórdica. Numa equivalência com as parcas, são também três as nornas: Urd, Verdandi e Skuld. Habitam perto ÁGORA FILOSÓFICA .v. 1. n. 2 (2014), pp.235-258 e-ISSN 1982-999x 
existe? Que tudo se reduz à linguagem ou à palavra? Soa-nos uma interpretação assaz plausível. O verso final do mesmo poema diz o seguinte: "Nenhuma coisa que seja onde a palavra faltar". Heidegger (2003, p. 125) parafraseou essa afirmação deste modo: "nenhuma coisa é onde falta a palavra". A palavra, e por que não a linguagem, cada vez mais se nos oferece como o fundamento do ser:

"Coisa", entende-se aqui no sentido tradicionalmente amplo de algo que de algum modo é. Nessa acepção, um deus é também uma coisa. Somente quando se encontra a palavra para a coisa, a coisa é coisa. Somente então ela é. Devemos portanto frisar bem: nenhuma coisa é, onde a palavra, isto é, o nome falhar. É a palavra que confere ser às coisas. Mas como pode uma simples palavra fazer isso, ou seja, conferir ser a alguma coisa? (HEIDEGGER, 2003, p. 125-126).

Ao falar da criação do esputinique, Heidegger (2003, p.126) explica que, só aparentemente, o satélite foi produzido e depois deram a ele um nome. Ele reflete, então, sobre as causas da elaboração desse satélite. Sua explicação é que a pressa, tão familiar no mundo moderno, já convocara e recomendara o homem para seu apelo. Se este não houvesse atendido a esse chamado, não haveria esputinique: "nenhuma coisa que seja onde a palavra faltar". A propósito, sobre sua paráfrase desse verso $^{11}$, Heidegger (2003, p. 129) alerta sobre o erro e a

da fonte chamada Urdarbrunn, aos pés das raízes da árvore do mundo. Decidem o destino de cada recém-nascido e tecem os fios que determinam o destino do mundo (N. da T.)." HEIDEGGER, M. A caminho da linguagem. Tradução de Marcia Sá Cavalcante Schuback. Petrópolis, RJ: Vozes; Bragança Paulista, SP: Editora Universitária São Francisco, 2003. p. 125.

${ }^{11}$ Tratamos um pouco das consequências da paráfrase em $2, \S 4^{\circ}$. ÁGORA FILOSÓFICA . v. 1. n. 2 (2014), pp.235-258 e-ISSN 1982-999x 
violência de imaginarmos a passagem de modo unívoco, o que podemos ampliar para o poema como um todo:

\begin{abstract}
Afirmar o sentido imperativo do "que seja" como o único possível seria, no entanto, por demais violento. É possível que, na saga poética do dizer, o "que seja" oscile entre um sentido e outro, entre o sentido do chamado como reivindicação e o de uma articulação e sintonia com o chamado.
\end{abstract}

Embora julguemo-nos criadores das coisas, a ciência, aliás, reforça em nós essa fantasia, colocando as ações acima das palavras, não somos nem mesmo autores do que falamos: "Em sua essência, a linguagem não é expressão e nem atividade do homem. A linguagem fala. O que buscamos no poema é o falar da linguagem. O que procuramos se encontra, portanto, na poética do que se diz" (HEIDEGGER, 2003, p.14).

A linguagem fala, como se ela tivesse vida própria. E nós? Nós podemos escutar. Os analistas do discurso, outrossim, reconhecem que não podemos controlar o sentido. Heidegger, brilhantemente, desvenda a causa disso a seu modo, visto que, para ele, não é o homem quem fala: "O homem fala à medida que corresponde à linguagem. Corresponder é escutar. Ele escuta à medida que pertence ao chamado da quietude." (HEIDEGGER, 2003, p. 26). Com base nisso, seria redundante mencionar a falta de controle dos sentidos de um discurso, porquanto o sentido não nos pertence. É a linguagem que dá não apenas sentido, mas sentidos ao texto. É ela a portadora dos sentidos. É ela. Ela é. 


\title{
5. HEIDEGGER: UM SEMÂNTICO DA ENUNCIAÇÃO?
}

\begin{abstract}
Antes mesmo do primeiro despertar de nossa consciência, as palavras já ressoavam à nossa volta, prontas para envolver os primeiros germes frágeis de nosso pensamento e a nos acompanhar inseparavelmente através da vida, desde as mais humildes ocupações da vida cotidiana até os momentos mais sublimes e mais íntimos dos quais a vida de todos os dias retira, graças às lembranças encarnadas pela linguagem, força e calor. A linguagem não é um simples acompanhante, mas sim um fio profundamente tecido na trama do pensamento; para o indivíduo, é o tesouro da memória e a consciência vigilante transmitida de pai para filho. Para o bem e para o mal, a fala é a marca da personalidade, da terra natal e da nação, o título de nobreza da humanidade. O desenvolvimento da linguagem está tão inextrincavelmente ligado ao da personalidade de cada indivíduo, da terra natal, da nação, da humanidade, da própria vida, que é possível indagar-se se ela não passa de um simples reflexo ou se ela não é tudo isso: a própria fonte do desenvolvimento dessas coisas.
\end{abstract}

Louis Trølle Hjelmslev ${ }^{12}$

Existem dois discursos centrais nos estudos semânticos sobre o significado. Um que toma a linguagem como instrumento de representação da realidade objetiva, a qual é exterior à linguagem. Esse ramo da semântica pode ser chamado de formal ou tradicional, e Gottlob Frege (1848-1925) é um dos seus representantes mais ilustres. No mito bíblico da criação, há um

12 HJElmsleV, L. T. Prolegômenos a uma teoria da linguagem. Tradução do inglês de José Teixeira Coelho Netto. 3. ed. São Paulo: Abril Cultural, 1985. p. 179. (Os Pensadores). 
trecho que expressa o ponto de vista de que as coisas podem existir sem a linguagem:

Havendo, pois, o Senhor Deus formado da terra todo o animal do campo, e toda a ave dos céus, os trouxe a Adão, para este ver como lhes chamaria; e tudo o que Adão chamou a toda a alma vivente, isso foi o seu nome. E Adão pôs os nomes a todo o gado, e às aves dos céus, e a todo o animal do campo [...] (Gênesis, cap. 2, vers. 19-20).

Essa é a explicação bíblica para como as coisas adquiriram seus nomes. Fica óbvia a preexistência delas em relação à palavra. Pode-se, inclusive, inferir que o mesmo se deu com todo o resto das coisas que precisassem ser nomeadas, não obstante isso não ser mencionado no texto. Esse pensamento aponta uma essência nas coisas como uma substância. A verdade não pode ser construção da linguagem, é anterior a ela. $\mathrm{O}$ mundo é externo à linguagem.

Apesar da aparência de saber mitológico, há uma convergência de visão de mundo, nesse ponto, entre religião e ciência, pois diríamos que subsiste uma tendência para uma valorização do discurso da semântica formal, pelo menos oficialmente, uma vez que vivemos numa época de vigor do cientificismo e continuamos a imaginar que, como Adão, nomeamos os entes. Todavia, como podemos estar equivocados se quase todos os dias vemos algo novo sendo primeiro inventado e só depois recebendo seu nome? Não foi assim com o esputinique? Não foi assim com tudo que existe?

Heidegger dá a resposta para essa pergunta. Ele argumenta que, mesmo quando vemos algo criado antes de seu nome, a palavra 
já nos encaminhou de alguma forma para essa coisa. No caso do esputinique e de outras invenções do mundo moderno, essa palavra foi pressa. Se não tivéssemos ouvido a pressa, não haveria satélites nem outras invenções afins.

É possível que tenhamos a ilusão de preexistir à linguagem porque as crianças nascem para só depois aprenderem a falar. Entretanto, sem sair da Bíblia, as coisas se dão do modo como é contado no Evangelho de João (cap. 1, vers. 01-04):

No princípio era o Verbo, e o Verbo estava com Deus, e o Verbo era Deus. Ele estava no princípio com Deus. Todas as coisas foram feitas por ele, e sem ele nada do que foi feito se fez. Nele estava a vida, e a vida era a luz dos homens.

Na verdade, mesmo em Gênesis já se encontra o poder criador da palavra, mas da palavra de Deus. Em João, no entanto, há uma igualdade entre a palavra (verbum, em latim) e Deus. De modo que o criador é a palavra, a palavra é o criador: "nenhuma coisa que seja onde a palavra faltar". Reiteramos que palavra pode ser pensada como linguagem nesse contexto.

Esse posicionamento situa Heidegger na semântica da enunciação ou na semântica lexical. Apesar da diferença nas expressões, ambas postulam que o significado não existe fora da linguagem $^{13}$ :

[...] para a Semântica da Enunciação, a referência é uma ilusão criada pela linguagem. Estamos sempre inseridos na linguagem: é o fato de que utilizamos dêiticos - termos cujo conteúdo é a remissão à externalidade

\footnotetext{
${ }^{13}$ Há diferença sutil entre semântica lexical e semântica da enunciação. A segunda expressão traz em si a ideia de uso concreto da linguagem. Contudo, estamos desprezando esses detalhes no nosso trabalho.$$
\text { ÁGORA FILOSÓFICA }
$$$$
\text { .v. 1. n. } 2 \text { (2014), pp.235-258 e-ISSN 1982-999x }
$$ 
linguística, os pronomes isto, eu, você, o artigo definido $o$, por exemplo - que nos dá a sensação/ilusão de estar fora da língua. [...] A Semântica Formal, diz Ducrot, cai na ilusão, criada pela própria linguagem, de que ela se refere a algo externo a ela mesma, de onde ela retira sua sustentação [...]; não falamos sobre o mundo, falamos para construir um mundo e a partir dele tentar convencer nosso interlocutor da nossa verdade, verdade criada pelas e nas nossas interlocuções. A verdade deixa, pois, de ser um atributo do mundo e passa a ser relativa à comunidade que se forma na argumentação [...] (OLIVEIRA, 2006, p. 28).

Tudo é linguagem por mais que queiramos insistir em imaginar que nomeamos as coisas. Uma mudança de palavra e temos um novo universo. Com a alteração dos critérios para definir o que é um planeta, Plutão desapareceu do sistema solar. Aprendemos na infância que nove eram os planetas. Hoje, tudo está mais fácil. Basta aos novos estudantes memorizarem oito. Brincadeiras à parte, fato é que mesmo os planetas que ainda permanecem no sistema solar, são o que são porque obedecem a critérios, isto é, algo predefinido pela linguagem.

Com efeito, a astronomia é mesmo um dos ramos do saber que mais nos torna céticos a respeito da objetividade do mundo. Faz cerca de mil e quinhentos anos que a Terra tornou-se redonda. Ninguém duvida de sua forma circular achatada nos polos, mas que segurança temos de que ela permanecerá assim até o final deste século? Em cem anos Plutão não existia, existiu e deixou de existir novamente. Qual foi de fato nossa relação com Plutão? Uma relação com a palavra, com o conhecimento astronômico, com a linguagem. Enquanto procurávamos esse astro no espaço, nem desconfiávamos que ele se encontrasse dentro de nós. Dentro de um homem cabe um planeta. 
Mais acima, cogitamos a possibilidade de a ilusão de uma linguagem referencial ser causada pelo fato de as crianças só começarem a falar bem depois que nascem. Por outro lado, é interessante notar que cada criança só tem consciência de si a partir da linguagem, que o mundo só tem existência para cada um de nós quando passamos a falar uma língua.

Que fique claro que pretendemos ressaltar um discurso em comum entre Heidegger e os semanticistas da enunciação. Decerto, não imaginamos que haja tal coincidência com muitas outras questões que discute o filósofo alemão; o que nos faz relacioná-los é a compreensão de que o mundo só existe, porque há linguagem, não o contrário, o que os une é a concepção de que a linguagem é o fundamento das coisas, e não um instrumento que aponta para uma verdade exterior a ela.

\section{CONSIDERAÇÕES FINAIS}

Heidegger é um autor que requer uma escuta demorada, que não busca ser compreendido no sentido trivial da palavra, mas que deseja ser ouvido, na verdade, que sabe que seu apelo só é audível por alguém pronto para uma experiência diversa com a linguagem, um indivíduo que permita que a linguagem fale.

A linguagem no mundo moderno tem perdido muito de seu vigor. Quanto mais a ratio se desenvolve, vigora, a linguagem

não pode aparecer. É por isso que a poesia recebe tanta importância, pois é nela que a linguagem pode aparecer como 
linguagem. Se voltarmos no tempo, é possível perceber que nos estamos distanciando da essência da linguagem, pois não havia o recorte científico e a ditadura da razão que impera nos dias atuais: a ilusão da exatidão e da objetividade. Embora tudo isso também seja linguagem, mas falta a totalidade inerente ao pensamento humano, no qual o lógico é minoria. De fato, o lógico pode ser uma ilusão criada a partir do ilógico, sua fonte em todos os sentidos — num sentido individual, da infância para a fase adulta, e num sentido social, já que a humanidade só convive há bem pouco tempo com uma verdade racional.

Quando nos deparamos com a polissemia, a falta de comunicação ou equívoco, quando não conseguimos dizer, aí, sim, a linguagem está-se mostrando verdadeiramente. Sendo assim, relacionar logos e razão já é parte do afastamento do homem da essência da linguagem. Só entendendo o que é de fato a essência da linguagem é que podemos compreender como essa ilusão também faz parte dela, no sentido de que não é ela, no sentido de que ela está confundindo-nos. Uma aparente contradição no pensamento de Heidegger? Mas se não for aparente, só serve para dar mais vigor às reflexões do filósofo. Heidegger não está comprometido com a coerência. A coerência só interessa a Heidegger como ilusão da linguagem, isto é, a partir de outra perspectiva do que seja coerência, uma espécie de invenção inverificável.

Heidegger interessa-se bastante pelo significado etimológico em suas análises. A etimologia enfrenta o problema de não sabermos onde está a origem, pois, em termos absolutos, o étimo perde-se no tempo. Porém, isso faz parte da essência da linguagem. Se podemos recuar sempre um pouco mais e achar 
um étimo mais original, se o sentido original sempre se esvai, já estamos então nos deparando com a essência das coisas no que elas têm de etéreo, que se dissolve; portanto, sem nenhuma substância: o ser. Isso resolve o problema socrático-platônico de busca por uma essência: "nada repousa sobre razão profunda". De certo modo, Heidegger recria o mundo das ideias de Platão, transformando tudo em palavras. Se concordarmos que não há ideia que possa ser pensada sem uma palavra equivalente, o pensador alemão corrige uma miragem do filósofo grego. Ao negar a essência das coisas e transferi-la para a linguagem, Heidegger aproxima-se dos sofistas.

Não apenas o mundo, mas também a linguagem são criações da própria linguagem. Isso pode nos levar a uma dupla ilusão: a da semântica tradicional, que pensa que falamos de uma realidade exterior à linguagem, que defende a existência de um mundo objetivo e a da semântica da enunciação, já que, mesmo conscientes do poder do verbum, não temos como falar dele de fora, vivemos uma espécie de efeito Münchhausen.

A partir disso, a relação entre Heidegger e os semanticistas da enunciação torna-se ainda mais distante, pois, ao notar o problema de se chegar à linguagem (essência) pela linguagem (deturpação), ele prioriza uma experiência com a linguagem. Há pontos em comum entre Heidegger e o espiritualismo. $\mathrm{O}$ fato de ser um irracionalista é um deles. A valorização da escuta é outro. Seu caminho para a linguagem pretende nos levar ao nirvana, a um zero absoluto. Para ele, o silêncio é mais linguagem que a linguagem. Precisamos falar nesses termos, mas, para Heidegger, a essência da linguagem está além dos dualismos. 


\section{REFERÊNCIAS BIBLIOGRÁFICAS}

ARQUIVO N. João Cabral de Melo Neto. Rio de Janeiro: Globo News, 2009.

Disponível em: https://www.youtube.com/watch?v=XvxWkAVVl-k>. Acesso em: 24 de fev. 2011.

BÍBLIA. Gênesis. Português. Bíblia Online. Almeida Corrigida e Revisada Fiel. Disponível em: <https://www.bibliaonline.com.br/acf/gn/2>. Acesso em: 28 fev. 2015.

. João. Português. Bíblia Online. Almeida Corrigida e Revisada Fiel. Disponível em: <https://www.bibliaonline.com.br/acf/jo/1>. Acesso em: 28 fev. 2015.

ETIMOLOGIA. In: WIKCIONÁRIO, o dicionário livre. Disponível em: <http://pt.wiktionary.org/wiki/etimologia>. Acesso em: 3 fev. 2015.

HEIDEGGER, M. A caminho da linguagem. Tradução de Marcia Sá Cavalcante Schuback. Petrópolis, RJ: Vozes; Bragança Paulista, SP: Editora Universitária São Francisco, 2003. 229 p.

HJELMSLEV, L. T. Prolegômenos a uma teoria da linguagem. Tradução do inglês de José Teixeira Coelho Netto. 3. ed. São Paulo: Abril Cultural, 1985. p. 177-214. (Os Pensadores).

NIETZSCHE, F. A Gaia Ciência. Tradução, notas e posfácio de Paulo César Lima de Souza. São Paulo: Companhia das Letras, 2001. 366p.

. Crepúsculo dos ídolos ou como se filosofa com o martelo. Tradução, apresentação e notas de Renato Zwick. Porto Alegre, RS: L\&PM, 2009. $144 \mathrm{p}$.

OLIVEIRA, R. P. Semântica. In: MUSSALIM, F: BENTES, A. C. (Org.). Introdução à lingüística: domínios e fronteiras. 5. ed. São Paulo: Cortez, 2006. p. 17-46. 
PIETROFORTE, A. V. S.; LOPES, I. C. A semântica lexical. In: FIORIN, J. L. (Org.). Introdução à lingüística II: princípio de análise. 4. ed. São Paulo: Contexto, 2010. p. 111-136.

SAUSSURE, Ferdinand de. Curso de lingüística geral. Organizado por Charles Bally e Albert Sechehaye. Tradução de Antônio Chelini, José Paulo Paes e Izidoro Blikstein. São Paulo: Editora Cultrix, 1977. 279p. 